\title{
Tata Kelola Perusahaan, Risiko Keuangan, dan Kinerja Perbankan di Indonesia
}

\author{
Agustin Ekadjaja dan Margarita Ekadjaja \\ Faculty of Economic and Business, Tarumanagara University \\ Email: \\ agustine@fe.untar.ac.id \\ margaritae@fe.untar.ac.id
}

\begin{abstract}
Abstrak: Keseimbangan shareholders dan stakeholders dalam pengelolaan perusahaan sejalan dengan prinsip Good Corporate Governanace (GCG). Perusahaan terkadang memerlukan tambahan dana eksternal dalam mengembangkan usahanya. Pemenuhan kebutuhan dana eksternal dapat diperoleh dari lembaga keuangan perbankan dan non perbankan. Penelitian ini bertujuan menilai kinerja perbankan, dengan mempertimbangkan proses tata kelola perusahaan (GCG) dan risiko keuangan bank. Populasi penelitian adalah perusahaan perbankan periode 2011 - 2018 dengan mengunakan regresi linier berganda sebagai alat analisis data. Hasil penelitian menemukan bahwa tata kelola perusahaan perbankan dan risiko keuangan memiliki implikasi terhadap kinerja perbankan. Variabel GCG, Net Interest Margin (NIM), dan Loan Deposit Ratio (LDR) memiliki hubungan searah terhadap kinerja perbankan. Variabel Non Performing Loan (NPL) dan Expense to Operating Income (ETOI) memiliki hubungan berlawanan arah, berarti bank harus menurunkan kredit bermasalah dan biaya operasional untuk meningkatkan kinerja banknya
\end{abstract}

\begin{abstract}
The balance of shareholders and stakeholders in managing the company is in line with the principles of Good Corporate Governance (GCG). Companies sometimes require additional external funds to develop their business. Fulfillment of external funding needs can be obtained from banking and non-banking financial institutions. The study population was banking companies for the period 2011 - 2018 using double linear regression as a data analysis tool. The results of the study found that banking corporate governance and financial risk have implications for banking performance.The results found that banking corporate governance and financial risk have implications for banking performance. The GCG variables, Net Interest Margin (NIM), and Loan Deposit Ratio (LDR) have a unidirectional relationship with banking performance. The variables of Non Performing Loan (NPL) and Expense to Operating Income (ETOI) have an opposite relationship, meaning that banks must reduce non-performing loans and operating costs to improve their bank performance.
\end{abstract}

Keywords: Good Corporate Governanace, Non Performing Loan, Net Interest Margin Loan Deposit Ratio, Expense to Operating Income. 


\section{PENDAHULUAN}

Menurut (Michael, 2017) kinerja berkontribusi secara ekonomis terhadap nilai perusahaan dan tujuan strategis suatu organisasi. Menurut (Wang et al., 2014) Manajer berkontribusi terhadap pengukuran kinerja perusahaan dalam pencapaian tujuan perusahaan. Menurut (Apătăchioae, 2015), melalui pengukuran kinerja perusahaan maka stakeholder dapat mengetahui ukuran dan nilai perusahaan tersebut. Berdasarkan pernyataan tersebut, maka pengukuran tercapainya tujuan dan arah kegiatan usaha tercermin dari tingkat kinerja perusahaan tersebut.

Perkembangan tata kelola perusahaan ditandai dengan pengelolaan perusahaan tidak lagi dominan untuk shareholders, tetapi juga stakeholders. Keseimbangan antara shareholders dan stakeholders dalam pengelolaan perusahaan tersebut sejalan dengan prinsip Good Corporate Governanace (GCG). Istilah GCG dalam konteks bahasa terdiri dari tiga suku kata, yaitu: good (baik), corporate (perusahaan), dan governance (pengaturan). Pelaksanaan GCG dikatakan baik jika perusahaan tersebut menjamin terlaksananya prinsip transparansi, accountability, responsibility, professional dan mengutamakan keadilan.

GCG ini mencerminkan perhatian shareholders melalui dewan komisaris terhadap kinerja perusahaan. Secara komprehensif GCG terdiri atas tiga bagian, yaitu: struktur, proses, dan hasil. Struktur GCG yang meliputi komisaris, direksi, komite, dewan pengawas. Proses GCG yang merupakan tersedianya kecukupan struktur dan infrastruktur sebagai jaminan efektivitas terlaksananya untuk menghasilkan governance outcome sesuai harapan stakeholders. Hasil GCG yang merupakan jaminan terpenuhinya harapan stakeholders terhadap hasil proses yang didukung kecukupan dari infrastruktur GCG.

Menurut (Chai et al., 2016), kemampuan perusahaan mencapai tujuan dapat diukur melalui kemampuan perusahaan tersebut mengelola sumber dananya baik secara internal seperti kemampuan dalam pencapaian profitabilitas maupun mengelola sumber dana secara eksternal yaitu dengan meningkatkan shareholder. Pemenuhan kebutuhan dana eksternal dapat diperoleh dari lembaga keuangan perbankan dan non perbankan, dimana perbankan berperan penting dalam perkembangan dan keseimbangan pertumbuhan ekonomi negara. Perbankan diharapkan dapat memaksimalkan keuntungan dan meningkatkan kestabilannya dalam menjalankan usahanya. Akan tetapi, tidaklah mudah bagi perbankan untuk selalu menjaga keuntungan maksimum karena besarnya risiko bisnis perbankan.

Menurut (French, 2019), risiko merupakan penyimpangan akibat ketidakpastian dan salah satu penyebab krisis finansial dunia pada tahun 2007-2008 adalah kesalahan dalam mengelola perusahaan dan memanajemen risiko perusahaan finansial yang berdampak sistemik. Keberhasilan dalam penerapan manajemen risiko tidak dapat dipisahkan dari jenis risikonya. Semakin besar harapan pencapaian kinerja maka risiko yang dihadapi akan bertambah. Hal ini dikarenakan perbankan menghadapi lingkungan bisnis yang dinamis. (Butaru et al., 2016) menyatakan dalam kegiatan komersial, perusahaan perbankan menghadapi risiko kredit dan risiko operasional sebagai bagian dari risiko yang terpenting. (Attar, et al., 2014) dan (Soyemi, et al., 2014) menyimpulkan adanya pengaruh yang penting dari efektivitas manajemen risiko terhadap unjuk kerja perbankan. Sementara hasil penelitian (Olamide, et al., 2015) membuktikan manajemen risiko tidak berpengaruh signifikan terhadap kinerja perbankan. 
(Haryati dan Kristijadi, 2015) meneliti bahwa penerapan tata kelola bank melalui pengukuran kinerja modal (CAR) untuk dapat memenuhi kategori profil resiko yang moderasi atau rendah akan tetapi jika dilihat dari profitabilitas (ROA) ada beberapa bank yang memiliki kriteria baik atau sangat baik, namun memiliki ROA yang cukup rendah 0,5\%-1,25\% dan bahkan dibawah 0,5\%. (Anginer, Demirguc-Kunt, Huizinga, \& Ma, 2018) menemukan bahwa bank yang menerapkan tata kelola perusahaan yang ramah terhadap pemegang saham memiliki risiko keuangan yang lebih tinggi terhadap kinerja bank tersebut.

Berdasarkan hasil penelitian tersebut dapat dilihat tidak selalu terdapat ketidaksesuaian antara kinerja perusahaan perbankan dengan penerapan tata kelola yang baik, sehingga diperlukan penelitian lebih lanjut sebagai bahan pertimbangan tambahan. Penelitian ini ditujukan untuk menganalisa pengaruh tata kelola perusahaan dan risiko keuangan perbankan terhadap kinerja perbankan, dengan sample penelitian dan tahun penelitian yang berbeda.

Menurut (Buchory, 2016) kinerja perbankan saat ini diarahkan kepada kebijakan pengawasan sektor perbankan sebaiknya difokuskan kepada pengembangan infrastruktur, sumber daya, dan 'methodology \& tools'. Terdapat beberapa model untuk menganalisa perbankan dan entitas perusahaan lainnya. Didalam perbankan sendiri, lingkungan perbankan baru dan meningkatnya ketidakstabilan pasar membutuhkan pendekatan terintegrasi untuk asset dan kewajiban dan teknis manajemen risiko.

Penelitian ini bertujuan sebagai tambahan terhadap metodologi yang sudah ada dengan membangun kerangka kerja yang komprehensif untuk penilaian kinerja perbankan, mempertimbangkan proses tata kelola perusahaan dan risiko keuangan perbankan, dengan demikian perumusan masalah penelitian adalah (1)Bagaimana implikasi tata kelola perusahaan terhadap kinerja perbankan (2) Bagaimana implikasi risiko keuangan terhadap kinerja perbankan.

\section{KAJIAN TEORI}

Setiap perusahaan diharapkan dapat terus tumbuh seiring meningkatnya persaingan jika perusahaan tersebut mampu mengatasi faktor eksternal dan internal perusahaan secara kondusif. Sejalan dengan hal tersebut, maka perusahaan memerlukan tambahan dana eksternal dalam mengembangkan usahanya. Pemenuhan kebutuhan dana eksternal dapat diperoleh dari lembaga keuangan perbankan dan non perbankan

Pemenuhan kebutuhan dana eksternal dapat diperoleh dari lembaga keuangan perbankan dan non perbankan. Pengukuran tingkat kesehatan bank menjadi hal yang krusial mengingat peran perusahaan perbankan terhadap perkembangan dan keseimbangan pertumbuhan perekonomian negara. Dalam penilaian tingkat kesehatan bank tercakup juga pengukuran besaran risiko perbankan. Skala peringkat risiko perbankan mencakup penilaian terhadap faktor-faktor yang meliputi: manajemen risiko bank, pengelolaan perusahaan (GCG), rentabilitas, dan kecukupan modal bank.

Dengan diterapkannya prinsip-prinsip tata kelola perusahaan perbankan yang baik menyebabkan animo masyarakat sebagai sumber dana pihak ketiga perusahaan perbankan untuk menginvestasikan dananya pada produk-produk perbankan yang ditawarkan, seperti tabungan, giro maupun deposito. Menurut meningkat (Riyadi dan Raffii, 2018), animo masyarakat dalam menginvestasikan dananya ke produk-produk perbankan, pada akhirnya 
akan mempertinggi sumber dana pihak ketiga perusahaan perbankan yang pada gilirannya kinerja perbankan juga meningkat. Pernyataan ini sejalan dengan hasil penelitian (Agrawal, 2013) bahwa perusahaan perbankan yang telah berhasil menata kelola perusahaannya secara kondusif dapat meningkatkan kinerja perusahaan perbankan tersebut.

Tata kelola perusahaan (Good Corporate Governance). Konsep Good Corporate Governance (GCG) semakin populer pada tahun 1970-an dengan hasil penelitian (Jensen dan Meckling, 1976) yang menggunakan pendekatan the agency theory untuk memahami fenonema corporate governance. Konsep GCG mulai menjadi perhatian kembali sejak terjadinya krisis keuangan dengan dilikuidasinya perusahaan raksasa seperti Enron dan WorldCom di AS akibat buruknya pelaksanaan GCG.

Dengan diterapkannya prinsip-prinsip Good Corporate Governance maka masyarakat luas percaya pada perusahaan perbankan tersebut, masyarakat akan mempercayakan penyimpanan uangnya baik berupa tabungan, giro maupun deposito pada perbankan tersebut, sehingga akan mempertinggi Dana Pihak Ketiga yang pada gilirannya kinerja perbankan pun meningkat (Riyadi dan Raffii, 2018). Pernyataan ini sejalan dengan hasil penelitian (Agrawal dan Knoeber, 2013) yaitu penerapan GCG yang baik dan benar akan meningkatkan laba/kinerja keuangan dari perbankan tersebut. Tanggung jawab untuk mempertahankan sistem perbankan dan pasar ditentukan ulang dalam negara yang satu dan yang lainnya, sebagai mitra diantara beberapa pemain utama yang menentukan beberapa dimensi risiko keuangan dan operasional yang berbeda. Kualitas manajemen perbankan dan proses manajemen risiko merupakan kunci dalam memastikan keamanan dan kestabilan dari perbankan itu sendiri dan sistem perbankan secara keseluruhan.

Tabel 1. Pengelolaan Kegiatan Usaha Bank

Pemain kunci dan tanggungjawab

Sistemik (pemain kunci) :

- Otoritas hukum dan peraturan : Menentukan kerangka kerja peraturan dan parameter manajemen resiko sektor perbankan

- Otoritas pengawas : Mengawasi kelangsungan hidup keuangan dan efektivitas manajemen resiko.

Institusional (pemain kunci) :

- $\quad$ Pemegang saham : Menunjuk board, manajemen, dan auditor

- Board of Directors : Menentukan kebijakan manajemen resiko dan sebagai penanggung jawab utama bank

- Manajemen eksekutif : Membuat sistem untuk menjalankan kebijakan perusahaan

- Komite audit/internal audit : Menguji kepatuhan kebijakan, memberikan jaminan tatakelola perusahaan baik, mengendalikan sistem dan proses manajemen resiko.

- $\quad$ Auditor eksternal : Memeriksa laporan keuangan dan evaluasi resiko

- $\quad$ Penanam modal/pendeposito : Mengerti hak dan tanggung jawab atas investasinya

- Lembaga pemeringkat dan media : Menginformasikan kepada publik dan menekankan kemampuan untuk melayani pinjaman

- Analis : Menganalisa informasi berdasarkan resiko

Sumber: Penulis, 2020 
Berdasarkan Tabel 1. Pengelolaan Kegiatan Usaha Bank menggambarkan kemitraan risiko manajemen yang mana setiap pemain utama memiliki akuntabilitas yang ditentukan dengan jelas untuk dimensi yang khusus dari setiap area yang berisiko. Pentingnya pengawasan perbankan dalam konteks tata kelola perusahaan mempertimbangkan pendekatan kemitraan dan kerangka kerja berkembang untuk tatakelola perusahaan dan manajemen risiko, demikian pula halnya dengan identifikasi dan alokasi dari tugas sebagai bagian dari proses manajemen risiko. Tata kelola perusahaan yang baik meliputi ukuran dan komposisi dewan, dualitas peran CEO dan chairman, kompensasi dewan, dan sebagainya yang semuanya memiliki keterkaitan dengan masalah keagenan dan biaya agensi. Masalah keagenan pada perusahaan perbankan sering kali terjadi antara masyarakat sebagai prinsipal dan manajemen bank sebagai agen dan bank sentral sebagai regulator. Berdasarkan struktur modal bank yang kompleks, maka implikasi keagenan terhadap asimetri informasi adalah adanya relasi antara pemilik, manajer, prinsipal (deposan), agen (bank), dan regulator (bank sentral).

Teori Informasi Asimetri. Penyingkapan dan transaparansi yang kurang dalam laporan keuangan, secara khususnya mengenai paparan risiko pasar terhadap risiko perusahaan dan bagaimana risiko tersebut mempengaruhi nilai perusahaan menimbulkan masalah informasi asimetri (Darrough dan Stoughton, 1986) Informasi asimetri timbul ketika beberapa bagian dari transaksi bisnis dapat memiliki keunggulan informasi dibanding yang lain.

Manajer sebagai orang dalam memiliki pengetahuan yang lebih besar dibandingkan pemegang saham, investor luar atau pemberi pinjaman mengenai risiko pasar saat ini dan prospek perusahaan ke depan. Mereka memiliki informasi yang lebih baik mengenai nilai tukar mata uang dan tingkat bunga yang dapat mempengaruhi pendapatan penjualan, piutang, dan arus kas. (Ekadjaja et al., 2020) Hal ini membuat manajemen memiliki posisi yang lebih baik untuk mengambil tindakan yang dibutuhkan untuk melakukan hedging terhadap risiko pasar. Sebaliknya, pemegang saham dan pemodal luar mengandalkan sepenuhnya dari informasi yang disampaikan oleh manajer perusahaan.

Pada saat informasi tidak lengkap dan timbul ketidakpastian teori agensi menempatkan masalah kedua agen sebagai berikut (Jensen dan Meckling, 1976) : Pilihan yang merugikan dimana pemegang saham tidak dapat secara langsung memastikan bahwa agen atau manajer selalu bertindak berdasarkan prinsip kepentingan terbaik, dan bahaya moral dimana prinsipal tidak yakin apakah para agen telah melakukan pekerjaannya sebaik yang mereka dapat lakukan.

Perspektif hubungan keagenan sebagai dasar yang digunakan dalam memahami corporate governance. Sesuai dengan teori agensi, principal dan agen memilki konflik karena perbedaan 'preferensi' risiko (Jensen dan Meckling, 1976) Prinsipal cenderung bersikap netral terhadap risiko karena mereka dapat melakukan diversifikasi risiko mereka pada perusahaan-perusahaan dan investasi mereka yang lain. Sebaliknya, para agen disebut memiliki keengganan karena risiko, oleh karenanya memiliki target yang berbeda dengan prinsipal. Jika dibiarkan tidak terdeteksi, para agen akan menata perusahaan sesuai dengan tujuan mereka.

Pemilik saham memiliki tantangan para manajer untuk bertindak sesuai harapan mereka. Karena perbedaan kepentingan antara para manajer dengan agen, maka diperlukan tata kelola perusahaan yang sejalan dengan kepentingan shareholders. Selain itu dengan 
adanyan penata kelola perusahaan secara baik dapat memotivasi manajer dalam memaksimalkan kesejahteraan shareholders.

Menurut (Nariman, 2018), tata kelola perusahaan memberikan insentif bagi dewan direksi dan manajemen untuk mengejar tujuan yang ada demi kepentingan terbaik para pemegang saham dan menyediakan struktur yang memantau hubungan di antara para pemegang saham, board of director, manajemen, dan pemegang saham lainnya dan mengarahkan perusahaan untuk mengendalikan biaya modal dan biaya transaksi dan memacu perusahaan untuk menggunakan sumber dayanya dengan lebih efisien. Tata kelola perusahaan menjadi dasar atau struktur perusahaan dalam penetapan dan pencapaian tujuan perusahaan yang secara tidak langsung meningkatkan kemampuan operasional perusahaan dan kebijakan manajemen yang mendukung kepentingan stakeholders.

Indikasi antar tata kelola perusahaan dengan teori agensi yaitu adanya kegiatan mengevaluasi dan memonitor mekanisme pengendalian kepemilikan saham terhadap konflik kepentingan manajemen (agency conflict). Tata kelola perusahaan berhubungan dengan masalah konflik kepentingan, merancang cara untuk mencegah kesalahan tindakan dan menyelaraskan kepentingan stakeholder dengan menggunakan insentif dan mekanisme pemantauan.

Tata kelola perusahaan yang baik meliputi ukuran dan komposisi dewan, dualitas peran CEO dan chairman, kompensasi dewan, dan sebagainya yang semuanya memiliki keterkaitan dengan masalah keagenan dan biaya agensi (Hamdani, 2016) Teori agensi mengarah kepada rekomendasi normatif dimana dewan harus memiliki mayoritas orang luar, idealnya direktur independen, dan orang yang berbeda pada posisi antara CEO dengan chairman.

Risiko yang dihadapi perbankan. Aktivitas utama perbankan adalah menyalurkan kredit yang dapat merupakan pendapatan bank dalam bentuk bunga. Pemberian dana kredit bank dapat meningkatkan jumlah pendapatan bank yang dapat mempengaruhi kinerja bank itu sendiri. Dalam hal penyaluran pinjaman, maka bank perlu memberikan perhatian terhadap kemungkinan risiko. 


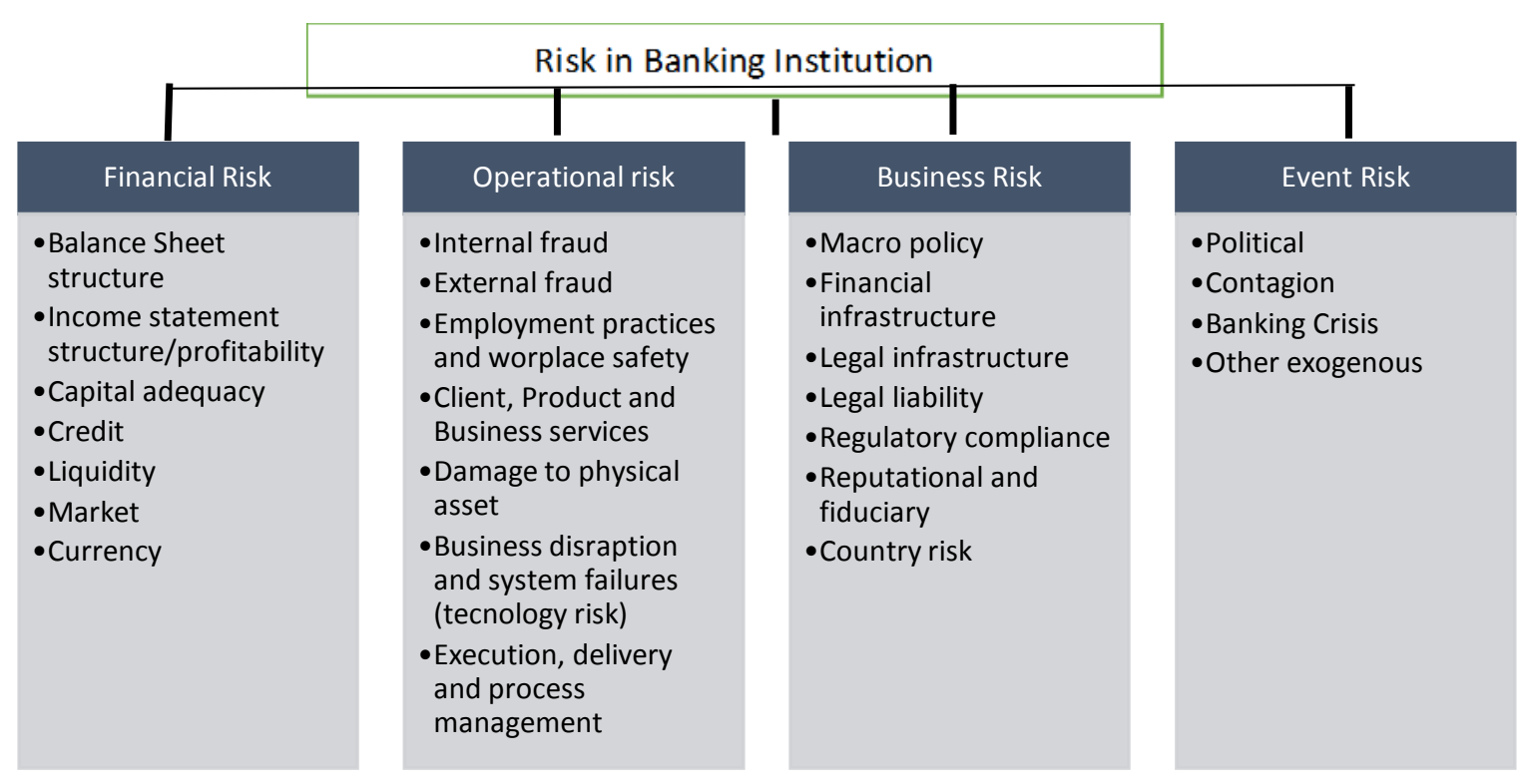

Gambar 2. Risiko Bank

Sumber: Penulis, 2020

Berdasarkan Gambar 1. Risiko Bank mendeskripsikan bahwa bank akan menghadapi risiko yang luas dalam kegiatan operasionalnya dan dikelompokan menjadi empat kategori risiko, yaitu: keuangan, operasional, bisnis dan peristiwa.

Kinerja Perbankan. Dengan semakin kompleksnya suatu usaha dan kemampuan perusahaan menanggapi resiko, maka perusahaan perbankan perlu memiliki kemampuan untuk mengidenfikasi masalah yang ada dalam operasional bank. Bagi perbankan, penilaian kinerja bank tersebut digunakan sebagai upaya pelaksanaan strategi usaha di masa mendatang. Manajemen pengelolaan tingkat kesehatan bank diperlukan dalam penilaian kinerja perusahaan perbankan tersebut. Hal tersebut dikarenakan kinerja bank merupakan gambaran keseluruhan dari presentase keberhasilan yang dicapai bank dalam pelaksanaan usahanya pada berbagai departemen.

Penilai kinerja keuangan bank dapat diukur melalui analisis dari faktor-faktor yang mempengaruhi kinerja bank. Indikator pengukuran yang lazim digunakan untuk mengukur profitabilitas bank menurut (Ostadi dan Monsef, 2014) adalah dengan pendekatan Return On Asset (ROA) dan pendekatan Return On Equity (ROE). Faktor-faktor utama dalam menilai kinerja keuangan bank meliputi: capital, asset, earning, dan liquidity. Dalam penilaian kinerja bank, peningkatan nilai usaha disertai dengan peningkatan pada profitabilitas dan risiko usaha bank.

(Olamide et al., 2014) melakukan studi dampak manajemen risiko yang efektif terhadap kinerja keuangan dari 14 perbankan yang terdaftar pada bursa saham Nigeria pada masa waktu 2006-2012. Mereka mendapati bahwa tidak adanya hubungan antara risiko kredit yang diukur melalui rasio NPL, dan terhadap kinerja keuangan perbankan yang diukur melalui ROA. 
(Attar et al., 2014) memeriksa efek dari penerapan risk management (meliputi risiko kredit, likuiditas dan operasional) terhadap kinerja keuangan dari perbankan yang terdaftar pada bursa saham Indonesia (IDX). Manajemen risiko diukur dengan menggunakan NPL, rasio pinjaman terhadap simpanan (LDR) dan pengeluaran dari pendapatan operasional (ETOI). Sementara unjuk kerja dari perbankan diukur dengan ROA dan ROE. Mereka menemukan bahwa implementasi dari manajemen risiko kredit, likuiditas dan operasional secara berkesinambungan mempengaruhi kinerja keuangan dari perbankan.

(Alshatti, 2015) melakukan studi untuk mengukur akibat dari manajemen risiko kredit terhadap kinerja keuangan 13 perbankan komersial di Jordania selama 2005-2013. Dia menyimpulkan bahwa risiko kredit memiliki pengaruh signifikan terhadap kinerja keuangan dari perbankan komersial di Yordania.

(Buchory, 2016) menganalisa efek dari risiko kredit terhadap keuntungan 26 perbankan pembangunan daerah. Hasil studi menunjukkan bahwa risiko kredit tidak memiliki hasil signifikan terhadap ROA.

(Million et al., 2015) menguji secara empiris akibat risiko kredit terhadap keuntungan dari delapan perbankan konvensional di Ethiopia. Hasil menunjukkan bahwa risiko kredit (NPL, provisi kerugian pinjaman, dan kecukupan modal) memiliki pengaruh signifikan terhadap keuntungan perbankan komersial di Ethiopia.

(Capriani dan Dana, 2016) melakukan studi akibat dari risiko kredit, risiko operasional, dan risiko likuiditas terhadap keuntungan dari perbankan daerah atau perbankan perkreditan rakyat (BPR) di Denpasar. Mereka melaporkan bahwa risiko kredit memiliki akibat yang positif tetapi tidak signifikan terhadap keuntungan perbankan.

(Soyemi et al., 2014) mempelajari hubungan rasio Non Performing Loan, rasio likuiditas, rasio ETOI (Expense to Operating Income), dan rasio kecukupan modal terhadap kinerja keuangan yang diukur dengan ROA dan ROE dari perbankan simpanan uang di Nigeria. Studi menggunakan contoh data dari 8 perbankan komersial yang dipilih. Hasil studi menemukan bahwa terdapat pengaruh yang penting dari praktek manajemen risiko terhadap kinerja keuangan perbankan. Indikator dari risiko pasar yang digunakan dalam penelitian memberikan dampak yang sangat kuat terhadap kinerja keuangan dari bank di Ghana.

Pengukuran profitabilitas dalam penelitian ini diproksikan oleh ROA, sedangkan pengukuran risiko bank diproksikan dengan rasio Non Performing Loan (NPL) untuk mengukur risiko kredit, Net Interest Margin (NIM) untuk mengukur risiko pasar, Loan Deposit Ratio (LDR) untuk mengukur risiko likuiditas, dan Expense to Operating Income (ETOI) untuk mengukur risiko operasional.

Menurut (Gugler dan Peev, 2018) profitabilitas bank di Amerika, Jerman, Inggris, Perancis, Itali, dan Swiss. Hasil penelitian (Gugler dan Peev, 2018) ditemukan profitabilitas bank dipengaruhi oleh krisis 2008-2013 dan kecukupan modal bank. Ukuran cara pengaturan biaya dan likuiditas bank mempunyai pengaruh terhadap profitabilitas sebelum, selama, dan sesudah krisis keuangan. Indikator pengukuran yang lazim digunakan untuk mengukur profitabilitas bank menurut (Ostadi dan Monsef, 2014) adalah dengan pendekatan Return On Asset (ROA) dan pendekatan Return On Equity (ROE).

Dalam penelitian ini alat ukur yang digunakan untuk mengukur profitabilitas adalah alat ukur yang digunakan oleh (Ostadi dan Monsef, 2014) di atas yaitu pendekatan ROA. Profitabilitas diukur dengan return on asset (ROA) yang merupakan perbandingan antara laba bersih setelah pajak terhadap total aset yang dimiliki oleh perusahaan. 
Tabel 2. Penelitian Terdahulu

\begin{tabular}{|c|c|c|}
\hline Nama Peneliti & Variabel & Hasil Penelitian \\
\hline $\begin{array}{c}\text { (Fang et al., } \\
\text { 2019) }\end{array}$ & Risiko insolvensi & $\begin{array}{l}\text { Perbankan umum di Cina dengan tingkat risiko insolvensi tinggi } \\
\text { memiliki profitabilitas yang lebih besar. Penelitian ini menemukan } \\
\text { bahwa kompetisi yang lebih tinggi memicu profitabilitas yang lebih } \\
\text { kecil pada industri perbankan China, dan perbankan komersial China } \\
\text { dengan tingkat efisiensi biaya yang lebih tinggi memiliki ROA yang } \\
\text { lebih tinggi. }\end{array}$ \\
\hline $\begin{array}{c}\text { (Nariman dan } \\
\text { Ekadjaja, 2018) }\end{array}$ & $\begin{array}{l}\text { Corporate } \\
\text { governance, } \\
\text { investment } \\
\text { opportunity set, firm } \\
\text { size, dan leverage }\end{array}$ & $\begin{array}{l}\text { Corporate Governance, investment opportunity set, dan firm size } \\
\text { berpengaruh signifikan terhadap earning quality yang dapat } \\
\text { memaksimalkan nilai perusahaan. Sedangkan leverage tidak } \\
\text { berpengaruh signifikan terhadap earning quality }\end{array}$ \\
\hline (Fanta, 2013) & $\begin{array}{l}\text { Corporate } \\
\text { Governance }\end{array}$ & $\begin{array}{l}\text { Corporate governance memiliki hubungan searah dan signifikan } \\
\text { terhadap kinerja bank. }\end{array}$ \\
\hline $\begin{array}{c}\text { (Olamide } \text { et al., } \\
\text { 2014) }\end{array}$ & NPL & $\begin{array}{l}\text { Dampak manajemen risiko yang efektif terhadap kinerja keuangan } \\
\text { dari } 14 \text { perbankan yang terdaftar pada bursa saham Nigeria dengan } \\
\text { kesimpulan hasil tidak adanya hubungan antara risiko kredit yang } \\
\text { diukur melalui rasio NPL, dan terhadap kinerja keuangan perbankan } \\
\text { yang diukur melalui ROA. }\end{array}$ \\
\hline $\begin{array}{c}\text { (Attar et al., } \\
\text { 2014) }\end{array}$ & Manajemen risiko & $\begin{array}{l}\text { Memeriksa efek dari penerapan risk management (meliputi risiko } \\
\text { kredit, likuiditas dan operasional) terhadap kinerja keuangan dari } \\
\text { perbankan yang terdaftar pada bursa saham Indonesia (IDX). } \\
\text { Manajemen risiko diukur dengan menggunakan NPL, rasio } \\
\text { pinjaman terhadap simpanan (LDR) dan pengeluaran dari } \\
\text { pendapatan operasional (ETOI). Sementara unjuk kerja dari } \\
\text { perbankan diukur dengan ROA dan ROE. Mereka menemukan } \\
\text { bahwa implementasi dari manajemen risiko kredit, likuiditas dan } \\
\text { operasional secara berkesinambungan mempengaruhi kinerja } \\
\text { keuangan dari perbankan. }\end{array}$ \\
\hline (Alshatti, 2015) & Risiko kredit & $\begin{array}{l}\text { Studi untuk mengukur akibat dari manajemen risiko kredit terhadap } \\
\text { kinerja keuangan } 13 \text { perbankan komersial di Jordania dengan } \\
\text { kesimpulan risiko kredit memiliki pengaruh signifikan terhadap } \\
\text { kinerja keuangan dari perbankan komersial di Yordania. }\end{array}$ \\
\hline (Buchory, 2016) & Risiko kredit & $\begin{array}{l}\text { Menyimpulkan efek dari risiko kredit terhadap keuntungan } 26 \\
\text { perbankan pembangunan daerah. Hasil studi menunjukkan bahwa } \\
\text { risiko kredit tidak memiliki hasil signifikan terhadap ROA. }\end{array}$ \\
\hline $\begin{array}{l}\text { (Million et al., } \\
\text { 2015) }\end{array}$ & NPL & $\begin{array}{l}\text { Menguji secara empiris akibat risiko kredit terhadap keuntungan dari } \\
\text { delapan perbankan konvensional di Ethiopia. Hasil menunjukkan } \\
\text { bahwa risiko kredit (NPL, provisi kerugian pinjaman, dan kecukupan } \\
\text { modal) memiliki pengaruh signifikan terhadap keuntungan } \\
\text { perbankan komersial di Ethiopia. }\end{array}$ \\
\hline $\begin{array}{l}\text { (Capriani dan } \\
\text { Dana, 2016) }\end{array}$ & Risiko kredit & $\begin{array}{l}\text { Melakukan studi akibat dari risiko kredit, risiko operasional, dan } \\
\text { risiko likuiditas terhadap keuntungan dari perbankan daerah atau } \\
\text { perbankan perkreditan rakyat (BPR) di Denpasar. Mereka } \\
\text { melaporkan bahwa risiko kredit memiliki akibat yang positif tetapi } \\
\text { tidak signifikan terhadap keuntungan perbankan. }\end{array}$ \\
\hline $\begin{array}{c}\text { (Soyemi et al., } \\
\text { 2014) }\end{array}$ & $\begin{array}{l}\text { Non Performing } \\
\text { Loan, rasio } \\
\text { likuiditas, rasio } \\
\text { ETOI (Expense to } \\
\text { Operating Income), }\end{array}$ & $\begin{array}{l}\text { Mempelajari hubungan rasio Non Performing Loan, rasio likuiditas, } \\
\text { rasio ETOI (Expense to Operating Income), dan rasio kecukupan } \\
\text { modal terhadap kinerja keuangan yang diukur dengan ROA dan } \\
\text { ROE dari perbankan simpanan uang di Nigeria. Studi menggunakan } \\
\text { contoh data dari } 8 \text { perbankan komersial yang dipilih. Hasil studi }\end{array}$ \\
\hline
\end{tabular}




\begin{tabular}{c|l|l}
\hline Nama Peneliti & \multicolumn{1}{|c}{ Variabel } & \multicolumn{1}{c}{ Hasil Penelitian } \\
\hline $\begin{array}{c}\text { (Zhongming et } \\
\text { al., 2019) }\end{array}$ & Recukupan modal & $\begin{array}{l}\text { menemukan bahwa terdapat pengaruh yang penting dari praktek } \\
\text { manajemen risiko terhadap kinerja keuangan perbankan. }\end{array}$ \\
\hline $\begin{array}{c}\text { (Drigă dan } \\
\text { Dura, 2014) }\end{array}$ & Resiko likuiditas & $\begin{array}{l}\text { Indikator dari risiko pasar yang digunakan dalam penelitian } \\
\text { memberikan dampak yang sangat kuat terhadap kinerja keuangan } \\
\text { dari bank di Ghana. }\end{array}$ \\
\hline $\begin{array}{c}\text { (Indonesia, } \\
\text { 2015) }\end{array}$ & $\begin{array}{l}\text { Risiko likuiditas berpengaruh signifikan terhadap kinerja bank. } \\
\text { Model penelitian menghubungkan rasio pendanaan bersih yang } \\
\text { stabil dengan kestabilan keuangan keseluruhan dengan menganalisa } \\
\text { data keuangan tahunan dari 948 bank di 85 negara (tidak termasuk } \\
\text { bank di Amerika utara dan Eropa). }\end{array}$ \\
\hline
\end{tabular}

Sumber: Penulis, 2020

Perumusan Hipotesis. Berikut gambar kerangka pemikiran penelitian yang menjelaskan perumusan hipotesis:

Variabel Independen

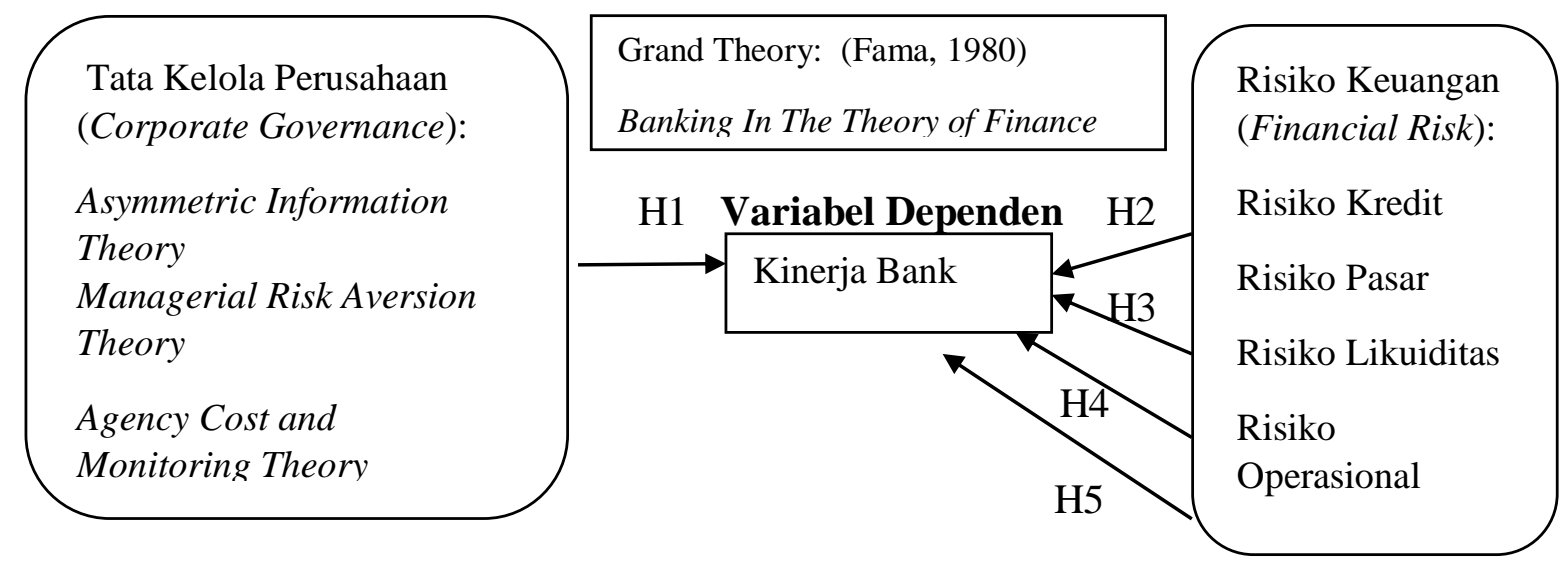

Gambar 2. Kerangka Pemikiran Penelitian Sumber: Penulis, 2020

Berdasarkan Gambar 2. Kerangka pemikiran penelitian mendeskripsikan perumusan hipotesis sebagai berikut:

Menurut (Anginer et al., 2018) perusahaan yang berhasil menata kelola dengan baik, maka dikatakan perusahaan tersebut dapat meningkatkan efisiensi, pertumbuhan, dan meningkatkan kepercayaan investor. Juga meningkatkan akses ke perusahaan keuangan eksternal, biaya modal yang lebih rendah dan meningkatkan unjuk kerja operasional (How et al., 2014). Menurut (Agrawal et al., 2013) pengelolaan perusahaan yang baik menunjukkan bahwa investor juga mau membayar biaya premi yang lebih besar untuk perusahaan dengan tatakelola perusahaan yang efektif. Menurut (Fanta, 2013), corporate governance memiliki hubungan positif signifikan terhadap kinerja bank. (Yegon, et al., 2014) menyatakan bahwa biaya agensi menjadi salah satu faktor kunci untuk melihat efisiensi dan efektifitas dari tata kelola perusahaan. Berdasarkan pernyataan di atas, maka perumusan hipotesis pertama penelitian adalah:

H1: Tata kelola perusahaan berpengaruh positif signifikan terhadap kinerja perbankan. 
Risiko kredit timbul jika perbankan memberikan fasilitas kredit kepada debitor yang memiliki risiko bahwa debitor tidak akan membayar kembali kewajibannya yang akan mengakibatkan penurunan keuntungan dari perbankan. Oleh karenanya, manajemen risiko kredit adalah penting untuk sebuah perbankan, karena manajemen risiko kredit mempengaruhi kinerja keuangan (Alshatti, 2015). Efektivitas dari manajemen risiko kredit pada perbankan dapat ditunjukkan dengan mengukur tingkat risiko kredit dengan menggunakan rasio pinjaman macet (NPL) karena NPL adalah petunjuk utama dalam mengukur risiko kredit dari perbankan komersial. Jika sebuah perbankan memiliki NPL yang rendah (5\%) menunjukkan lemahnya manajemen risiko kredit diterapkan.

Sementara (Buchory, 2016) menganalisa efek dari risiko kredit terhadap keuntungan perbankan pembangunan daerah. Hasil studi menunjukkan bahwa risiko kredit tidak memiliki hasil signifikan terhadap ROA. Berdasarkan pernyataan diatas, maka perumusan hipotesis ke dua penelitian yaitu:

H2: Risiko kredit berpengaruh negatif signifikan terhadap kinerja perbankan.

Risiko pasar bank adalah risiko kehilangan dalam portofolio cair yang diakibatkan oleh pergerakan dalam harga pasar dan terdiri atas tingkat suku bunga, mata uang, ekuitas dan risiko komoditas. Teori manajemen resiko dikembangkan oleh (Pyle, 1999) dengan tujuan untuk mempelajari mengapa manajemen resiko dibutuhkan, dan bagaimana bank harus mengelola risiko seperti risiko kredit dan pasar. Teori tersebut menentukan bahwa resiko kredit dan pasar keduanya akan memiliki dampak langsung maupun tidak langsung terhadap keberlangsungan bank (Trad et al., 2017)

Menurut (Zhongming et al., 2019) indikator dari risiko pasar yang digunakan dalam penelitian memberikan dampak yang sangat kuat terhadap kinerja keuangan dari bank di Ghana. Hasil penelitian menemukan analisa sebab akibat mengungkapkan bahwa hubungan sebab akibat bergerak searah dari indikator risiko pasar menuju pengembalian asset (ROA). Hal ini membuktikan bahwa adanya pengaruh dari risiko keuangan terhadap kinerja keuangan bank pada sektor perbankan di Ghana. Berdasarkan pernyataan diatas, maka perumusan hipotesis ke tiga penelitian yaitu:

H3: Risiko pasar berpengaruh positif signifikan terhadap kinerja perbankan.

Perbankan akan menghadapi risiko kelebihan dan kekurangan dana sehubungan dengan likuiditas perbankan. Menurut (Drehmann dan Nikolaou, 2013), jika sebuah bank memiliki kelebihan dana (dana menganggur), perbankan akan menghadapi pengorbanan suku bunga yang tinggi. Sebaliknya, jika sebuah perbankan menghadapi kekurangan dana, perbankan akan menghadapi kesulitan dalam memenuhi kewajiban jangka pendeknya. Maka, dapat terjadi konflik kepentingan antara mencari keuntungan yang besar atau menjaga likuiditas yang besar, karena saat perbankan mengharapkan keuntungan yang besar maka akan menyebabkan risiko pada likuiditas perbankan yang akan menjadi rendah. Sebaliknya, jika tingkat likuiditas perbankan tinggi, tingkat keuntungan yang diperoleh akan menjadi rendah. Sesuai dengan Peraturan Perbankan Indonesia (PBI) nomor; 12/19/PBI/2010, tingkat ideal dari LDR untuk perbankan komersial adalah diantara 78\% dan $100 \%$.

Menurut (Drigă dan Dura, 2014), resiko likuiditas berpengaruh signifikan terhadap kinerja bank. Model penelitian menghubungkan rasio pendanaan bersih yang stabil dengan 
kestabilan keuangan keseluruhan dengan menganalisa data keuangan tahunan dari 948 bank di 85 negara (tidak termasuk bank di Amerika Utara dan Eropa) tahun 2003 sampai 2013. Berdasarkan pernyataan diatas, maka perumusan hipotesis ke empat penelitian adalah:

H4: Risiko likuiditas berpengaruh positif signifikan terhadap kinerja perbankan.

Penyimpangan dari kegiatan perusahaan disebut risiko operasional perusahaan. Hasil penelitian (Karim dan Alam, 2013) menyatakan bahwa risiko risiko operasional berpengaruh terhadap kinerja bank. Sementara itu, Menurut (Capriani dan Dana, 2016) kegagalan perusahaan perbankan dalam mengendalikan risiko operasional dapat mempengaruhi kinerja perusahaan perbankan tersebut. Jika perbankan tidak dapat menyelesaikan risiko operasional yang dihadapinya, maka tingkat keuntungan perbankan akan berkurang. Oleh karenanya, manajemen risiko yang berhubungan dengan risiko operasional dapat berdampak pada tingkat keuntungan perbankan.

Rasio yang digunakan untuk mengukur risiko operasional adalah ETOI. Berdasarkan peraturan perbankan Indonesia nomor 6/23/SEBI/2004, kriteria penilaian rasio ETOI adalah 95\%. Rasio ETOI yang melebihi 95\% menunjukkan bahwa perbankan menghadapi peningkatan biaya operasional yang tinggi dibandingkan dengan pendapatannya dan risiko operasional yang dihadapi perbankan tinggi. Hal ini menunjukkan bahwa perbankan kurang efisien dalam mengurangi biaya operasionalnya, oleh karena itu berdampak pada keuntungan perbankan. Kurangnya efisiensi perbankan dalam mengurangi biaya operasional menunjukkan belum dapat menerapkan manajemen risiko dengan efektif.

Sebaliknya, jika rasio ETOI $<95 \%$, tingkat risiko operasional perbankan tersebut rendah, yang menunjukkan bahwa perbankan mampu menjalankan manajemen risiko operasional dengan baik. Berdasarkan pernyataan diatas, maka perumusan hipotesis ke lima penelitian adalah:

H5: Risiko operasional berpengaruh negatif signifikan terhadap kinerja perbankan.

\section{METODE}

Desain Penelitian. Penelitian ini bersifat asosiatif karena mempertanyakan hubungan antara variabel independen dengan variabel dependen (Sugiyono, 2016). Data penelitian diambil dari laporan keuangan perusahaan sektor perbankan dengan skor coporate governance tertinggi versi IICD tahun 2019.

Dalam penelitian ini, risiko keuangan diukur menggunakan rasio keuangan, meliputi rasio Non Performing Loan (NPL) untuk mengukur risiko kredit, Net Interest Margin (NIM) untuk mengukur risiko pasar, Loan Deposit Ratio (LDR) untuk mengukur risiko likuiditas, dan Expense to Operating Income (ETOI) untuk mengukur risiko operasional. Sedangkan kinerja perbankan sebagai variabel dependen dalam penelitian ini diukur dengan menggunakan Return On Asset (ROA).

Metode pemilihan sampel. Populasi dalam penelitian ini adalah perusahaan perbankan yang terdaftar di indeks tata kelola perbankan periode 2011-2018. Pemilihan sampel menggunakan metode purposive sampling (sesuai dengan kriteria) dalam penelitian. 
Berdasarkan kriteria diperoleh 11 perusahaan perbankan yang memenuhi, sehingga total data penelitian dapat lebih dari 88 observasi.

Operasional Variabel. Definisi variabel dari penelitian ini berdasarkan pengertian dan arti dalam penelitian sebelumnya. Variabel dalam penelitian ini terdiri atas : variabel dependen yaitu kinerja perbankan yang diukur dengan ROA, variabel independen yaitu tata kelola perusahaan (GCG) yang diukur dengan Asean Corporate Governance Scorecard, risiko keuangan, dan risiko operasional yang diukur dengan NPL, NIM, LDR, dan ETOI.

Berikut merupakan model persamaan penelitian:

$$
Y_{i, t}=\beta_{0}+\beta_{1} \text { GCG }_{i, t}-\beta_{2} \text { NPL }_{i, t}+\beta_{3} \text { NIM }_{i, t}+\beta_{4} \text { LDR }_{i, t}-\beta_{5} \text { ETOI }_{i, t}+e_{i, t} \ldots . . \text { (1) }
$$

$$
\begin{array}{ll}
\text { Keterangan: } & \text { Y } \\
\text { GCG } & =\text { Return On Asset } \\
\text { NPL } & =\text { Non Performing Loan } \\
\text { NIM } & =\text { Net Interest Margin } \\
\text { LDR } & =\text { Loan to Deposit Ratio } \\
\text { ETOI } & =\text { Expense to Operating Income }
\end{array}
$$

\begin{tabular}{|c|c|c|c|c|c|}
\hline No & Variabel & Definisi & Indikator & Pengukuran & Skala \\
\hline \multicolumn{6}{|c|}{ Variabel Dependen } \\
\hline 1 . & $\begin{array}{l}\text { Profitabilitas } \\
\text { Perbankan } \\
\text { Umum }\end{array}$ & $\begin{array}{l}\text { Kemampuan } \\
\text { Perbankan } \\
\text { Umum untuk } \\
\text { memperoleh } \\
\text { keuntungan }\end{array}$ & ROA & $\begin{array}{l}\text { Laba bersih dibagi } \\
\text { dengan total asset } \\
\text { (Taswan, 2015) }\end{array}$ & Rasio \\
\hline \multicolumn{6}{|c|}{ Variabel Independen } \\
\hline 1. & $\begin{array}{l}\text { Tata Kelola } \\
\text { Perusahaan }\end{array}$ & $\begin{array}{l}\text { Hubungan } \\
\text { antara pemilik, } \\
\text { manajemen, dan } \\
\text { dewan komisaris }\end{array}$ & $\begin{array}{l}\text { Assessment } \\
\text { Corporate } \\
\text { Governance }\end{array}$ & $\begin{array}{l}\text { Asean Corporate } \\
\text { Governance } \\
\text { Scorecard }\end{array}$ & $\begin{array}{l}\text { Skor } \\
\text { Index }\end{array}$ \\
\hline 2. & $\begin{array}{l}\text { Risiko } \\
\text { Keuangan } \\
\text { Bank }\end{array}$ & $\begin{array}{l}\text { Perbandingan } \\
\text { usaha perbankan } \\
\text { dalam rangka } \\
\text { meningkatkan } \\
\text { kinerja } \\
\text { perbankan }\end{array}$ & $\begin{array}{l}\text { NPL (Non } \\
\text { Performing } \\
\text { Loan) } \\
\text { NIM } \\
\text { LDR } \\
\text { ETOI }\end{array}$ & $\begin{array}{l}\text { Total kredit } \\
\text { bermasalah dibagi } \\
\text { total kredit yang } \\
\text { diberikan } \\
\text { Pendapatan Bunga } \\
\text { Bersih dibagi Total } \\
\text { Aktiva Produktif } \\
\text { Total kredit dibagi } \\
\text { total deposit } \\
\text { Biaya Operasional } \\
\text { dibagi Pendapatan } \\
\text { operasional }\end{array}$ & Rasio \\
\hline
\end{tabular}

Tabel 3. Operasionalisasi Variabel

Sumber : (Kasmir, 2014) 


\section{HASIL DAN PEMBAHASAN}

Tata kelola perusahaan yang baik menuntut perusahaan untuk memiliki kebijakan manajemen risiko. Manajemen risiko merupakan alat dalam mekanisme tata kelola perusahaan dan tidak dapat berjalan baik tanpa adanya fungsi pengawasan dari tata kelola perusahaan. Penelitian ini didesain untuk menganalisis tata kelola perusahaan, risiko keuangan, dan kinerja perbankan di Indonesia. Orientasi penelitian ini adalah mengetahui tata kelola perusahaan pada bidang perbankan di Indonesia yang diukur dengan Asean Corporate Governance Scorecard dan pengaruh risiko keuangan terhadap kinerja perbankan di Indonesia. Variabel dalam penelitian ini terdiri atas: variabel dependen yaitu kinerja perbankan yang diukur dengan ROA, variabel independen yaitu tata kelola perusahaan (GCG) yang diukur dengan Asean Corporate Governance Scorecard, risiko keuangan, dan risiko operasional yang diukur dengan NPL, NIM, LDR, dan ETOI.

Tabel 4. Statistik Deskriptif

\begin{tabular}{l|l|l|l|l|l|l}
\hline \hline & \multicolumn{1}{|c|}{ ROA } & \multicolumn{1}{c}{ GCG } & \multicolumn{1}{c}{ NIM } & NPL & LDR & ETOI \\
\hline Mean & 2.609318 & 80.67739 & 6.111477 & 1.027955 & 82.72773 & 3.352045 \\
\hline Median & 2.620000 & 85.32000 & 5.935000 & 0.685000 & 85.85000 & 2.295000 \\
\hline Maximum & 5.150000 & 93.32000 & 10.77000 & 4.230000 & 98.05000 & 17.69000 \\
\hline Minimum & 0.160000 & 0.000000 & 3.590000 & 0.020000 & 50.27000 & 0.820000 \\
\hline Std. Dev. & 1.057807 & 18.31793 & 1.531160 & 0.970212 & 9.939514 & 2.903411 \\
\hline Skewness & 0.208064 & -3.904473 & 0.668061 & 1.181242 & -1.120157 & 2.385206 \\
\hline Kurtosis & 2.771650 & 17.52580 & 3.187920 & 3.525890 & 3.958837 & 10.46209 \\
\hline & & & & & & \\
\hline JarqueBera & 0.826124 & 997.2541 & 6.675293 & 21.47893 & 21.77403 & 287.6119 \\
\hline Probability & 0.001621 & 0.000000 & 0.035520 & 0.000022 & 0.000019 & 0.000000 \\
\hline Sum & 229.6200 & 7099.610 & 537.8100 & 90.46000 & 7280.040 & 294.9800 \\
\hline Sum Sq.Dev. & 97.34916 & 29192.56 & 203.9671 & 81.89403 & 8595.073 & 733.3920 \\
\hline
\end{tabular}

Sumber: Hasil Olahan Penulis, 2020

Berdasarkan Tabel 4. Statistik Deskriptif teridentifikasi bahwa probability atas Jarque-Bera dengan tingkat signifikansi 95\% ( $\mathrm{a}=5 \%)$ maka variabel ROA, CGC, NPL, NIM, LDR, dan ETOI terdistribusi secara normal dan nilai standar deviasinya lebih kecil dari nilai rataratanya. Hal ini menunjukkan bahwa penyimpangan data terhadap nilai rataratanya rendah, sehingga tidak terdapat data ekstrim yang dapat menimbulkan bias pada hasil penelitian.

Rata-rata nilai tata kelola perusahaan perbankan adalah 80,67739, dengan nilai maksimum 93,32 yang diperoleh oleh Bank Mandiri pada tahun 2015. Nilai minimum tata kelola perusahaan perbankan sebesar 0.00000 menunjukkan berdasarkan data pada CGPI (Corporate Governance Perception Index) tahun 2011-2018 ada perusahaan yang nilai tata kelolanya tidak dinyatakan dalam angka. 
Rata-rata NIM (Net Interest Margin) sebesar 6.111477\% menunjukkan bahwa bank di Indonesia berada pada posisi sangat sehat yaitu nilai NIM $(6.111477 \%)<12 \%$. Dengan nilai maksimum 10.77000 dan nilai minimum 3.590000. Variabel NIM memiliki nilai tengah (median) 5.935000 dengan standar deviasi sebesar 1.531160 .

Rata-rata NPL (Non Performing Loan) sebesar 1.027955 yang menunjukkan bahwa berdasarkan kriteria penetapan peringkat profil risiko bank di Indonesia adalah sangat sehat karena berada pada posisi NPL $<2 \%$ (PBI No 6/23/DPNP tahun 2004). Variabel NPL memiliki nilai tengah (median) 0,685000 dengan standar deviasi sebesar 0,970212. Nilai maksimum sebesar 4,230000 dan nilai minimum sebesar 0,020000.

LDR sebesar 82.72773 menunjukkan bahwa kriteria bank di Indonesia dilihat dari sisi Loan Deposit Ratio (LDR) bank tersebut berada pada kriteria cukup sehat, terbukti dari nilai LDR bank di Indonesia termasuk dalam kategori bank cukup sehat $(85 \%<\mathrm{LDR} \leq 100 \%)$. Variabel LDR memiliki nilai rata-rata (mean) sebesar 82.72773 dan nilai tengah (median) 85,85000 dengan standar deviasi sebesar 9.939514.

ETOI sebesar $3.352045 \%$ menunjukkan bahwa risiko operasional bank rendah. Berdasarkan peraturan Bank Indonesia Nomor: 6/23 / SEBI / 2004, kriteria penilaian rasio ETOI (Expense to Operating Income) adalah 95\%. Rasio ETOI yang melebihi 95\% menunjukkan bahwa bank memiliki biaya operasi yang lebih tinggi dibandingkan dengan pendapatan operasinya sehingga risiko operasional yang dihadapi bank tinggi. Ini menunjukkan bahwa bank kurang efisien dalam mengendalikan biaya operasionalnya, dengan demikian mempengaruhi profitabilitas bank. Kurangnya efisiensi bank di Indonesia dalam mengurangi biaya operasinya menunjukkan bahwa bank belum mampu untuk menerapkan manajemen risiko secara efektif. Sebaliknya, ketika Rasio ETOI <95\%, tingkat risiko operasional perbankan rendah, yang menunjukkan bahwa bank telah dapat melakukan operasional manajemen risiko dengan baik. Besarnya median ETOI perusahaan perbankan sebesar 2.295000 dan standar deviasi sebesar 2.903411.

Demikian dengan nilai ROA bank di Indonesia sebesar 2.609318 menunjukkan bahwa bank tersebut terkategori sangat sehat, terlihat pada ROA pada perusahaan perbankan yang terkategori dalam Asean Coporate Governance Scorecard tahun 2011-2018 ( 2.212435) tergolong kriteria bank sangat sehat $(\mathrm{ROA}>1,5 \%)$. Variabel ROA memiliki nilai tengah (median) 2.62000 dengan standar deviasi sebesar 1.057807 .

\section{Pengujian Model Regresi Data Panel}

Tabel 5. Uji Chow

\begin{tabular}{lrrr}
\hline Effects Test & Statistic & d.f. & Prob. \\
\hline \hline Cross-section F & 13.929311 & $(10,72)$ & 0.0000 \\
Cross-section Chi-square & 94.739057 & 10 & 0.0000
\end{tabular}

Sumber: Penulis, 2020

Tabel 5. Menunjukkan bahwa probabilitas Cross-section Chi-square bernilai 0 sehingga model regresi data panel yang sebaiknya digunakan adalah fixed effects model atau random effects model sehingga pengujian model regresi data panel akan dilanjutkan dengan menggunakan uji Hausman. 
Tabel 6. Uji Hausman

\begin{tabular}{lcrc}
\hline & $\begin{array}{c}\text { Chi-Sq. } \\
\text { Statistic }\end{array}$ & $\begin{array}{r}\text { Chi-Sq. } \\
\text { d.f. }\end{array}$ & Prob. \\
\hline \hline Cross-section random & 12.752774 & 5 & 0.0258 \\
\hline \hline
\end{tabular}

Sumber: Penulis, 2020

Tabel 6. Menunjukkan bahwa probabilitas Cross-section random bernilai 0.0258 sehingga model regresi data panel yang sebaiknya digunakan adalah fixed effects model.

Tabel 7. Koefisien Regresi

Dependent Variable: ROA

Method: Panel Least Squares

Periods included: 8

Cross-sections included: 11

Total panel (balanced) observations: 88

\begin{tabular}{|c|c|c|c|c|}
\hline Variable & Coefficient & Std. Error & t-Statistic & Prob. \\
\hline $\mathrm{C}$ & 2.074371 & 0.611345 & 3.393128 & 0.0011 \\
\hline GCG & 0.005878 & 0.002772 & 2.120414 & 0.0374 \\
\hline NIM & 0.093218 & 0.053931 & 1.728473 & 0.0882 \\
\hline NPL & -0.472436 & 0.114105 & -4.140368 & 0.0001 \\
\hline LDR & 0.003498 & 0.005941 & 0.588705 & 0.5579 \\
\hline ETOI & -0.093270 & 0.023442 & -3.978690 & 0.0002 \\
\hline \multicolumn{5}{|c|}{ Effects Specification } \\
\hline \multicolumn{5}{|c|}{ Cross-section fixed (dummy variables) } \\
\hline R-squared & 0.886263 & \multicolumn{2}{|c|}{ Mean dependent var } & 2.609318 \\
\hline $\begin{array}{l}\text { Adjusted R- } \\
\text { squared }\end{array}$ & 0.862567 & \multicolumn{2}{|c|}{ S.D. dependent var } & 1.057807 \\
\hline S.E. of regression & 0.392149 & \multicolumn{2}{|c|}{ Akaike info criterion } & 1.128617 \\
\hline Sum squared resid & 11.07223 & \multicolumn{2}{|c|}{ Schwarz criterion } & 1.579041 \\
\hline Log likelihood & -33.65913 & \multicolumn{2}{|c|}{ Hannan-Quinn criter. } & 1.310081 \\
\hline F-statistic & 37.40253 & \multicolumn{2}{|c|}{ Durbin-Watson stat } & 1.318062 \\
\hline Prob(F-statistic) & 0.000000 & & & \\
\hline
\end{tabular}

Sumber: Penulis, 2020

Tabel 7 menunjukan hasil uji analisis regresi linear berganda dengan menggunakan fixed effect model. Persamaan regresi yang digunakan dalam penelitian ini mengacu pada hasil uji analisis regresi linear berganda di atas adalah: 
$\mathrm{ROA}=2.0743+0.0059 \mathrm{GCG}_{\mathrm{i}, \mathrm{t}}+0.0932 \mathrm{NIM}_{\mathrm{i}, \mathrm{t}}-0.4724 \mathrm{NPL}_{\mathrm{i}, \mathrm{t}}+0.0035 \mathrm{LDR}_{\mathrm{i}, \mathrm{t}}-0,0933_{\mathrm{i}, \mathrm{t}}+\mathrm{e} . .(2)$ Dimana: $\mathrm{i}=$ perusahaan dan $\mathrm{t}=$ Tahun

Persamaan regresi menunjukkan bahwa tata kelola perusahaan perbankan (GCG) memiliki nilai koefisien regresi sebesar 0.0059 . Nilai positif yang terdapat dalam koefisien regresi menunjukkan bahwa tata kelola perusahaan memiliki pengaruh positif signifikan terhadap kinerja perusahaan.

Persamaan regresi menunjukkan bahwa risiko pasar perusahaan perbankan yang diproksikan dengan NIM (Net Interest Margin) memiliki nilai koefisien regresi sebesar 0.0932. Nilai positif yang terdapat dalam koefisien regresi menunjukkan bahwa risiko pasar memiliki pengaruh positif signifikan terhadap kinerja perusahaan perbankan.

Persamaan regresi yang digunakan menunjukkan bahwa risiko kredit perusahaan perbankan yang diproksikan dengan NPL (Net Performing Loan) memiliki nilai koefisien regresi sebesar -0.4724 . Nilai negatif yang terdapat dalam koefisien regresi menunjukkan bahwa risiko pasar memiliki pengaruh negatif signifikan terhadap ROA dengan tingkat signifikansi $95 \%$.

Persamaan regresi yang digunakan menunjukkan bahwa LDR memiliki nilai koefisien regresi sebesar 0.0035 . Nilai positif yang terdapat dalam koefisien regresi menunjukkan bahwa risiko likuiditas yang diproksikan LDR (Loan Deposit Ratio) memiliki pengaruh positif namun tidak signifikan terhadap ROA.

Persamaan regresi yang digunakan menunjukkan bahwa risiko operasional perusahaan perbankan yang diproksikan dengan ETOI (Earning to Operating Income) memiliki nilai koefisien regresi sebesar -0.0933. Nilai negatif yang terdapat dalam koefisien regresi menunjukkan bahwa risiko operasional perusahaan perbankan memiliki pengaruh negatif signifikan terhadap ROA dengan tingkat signifikansi $95 \%$.

Hasil Uji secara simultan (uji F) merupakan pengujian yang dilakukan untuk mengetahui apakah seluruh variabel bebas secara bersama-sama mampu mempengaruhi variabel terikat yang digunakan dalam penelitian. Koefisien Regresi menunjukkan nilai probability ( $F$-statistic) sebesar $0,000000 . \mathrm{H}_{0}$ diterima sehingga tata kelola $(\mathrm{GCG})$, risiko pasar (NIM), risiko kredit (NPL), risiko likuiditas (LDR), dan risiko operasional (ETOI) perusahaan perbankan secara bersama-sama mampu mempengaruhi kinerja perusahaan perbankan (ROA).

GCG, NIM, NPL, dan ETOI memiliki nilai probability $<0,05$ menunjukkan bahwa $\mathrm{H}_{0}$ diterima sehingga tata kelola, risiko pasar, risiko kredit, dan risiko operasional perusahaan secara parsial mampu mempengaruhi kinerja perbankan yang diproksikan ROA.

Koefisien Regresi menunjukkan LDR memiliki nilai probability sebesar 0.5579. Nilai probability $>0,05$ menunjukkan bahwa $\mathrm{H}_{0}$ ditolak sehingga risiko likuiditas bank secara parsial tidak mampu mempengaruhi kinerja perusahaan perbankan.

Nilai Adjusted $R$-squared sebesar 0.862567 menunjukkan bahwa variabel bebas dalam penelitian ini yaitu GCG, NIM, NPL, LDR, dan ETOI mampu menjelaskan variabel terikat dalam penelitian ini yaitu ROA sebesar 0.862567 atau $86,26 \%$. Variabel terikat yang digunakan dalam penelitian ini yaitu ROA juga dipengaruhi oleh faktor lain selain GCG, NIM, NPL, LDR, dan ETOI sebesar 13,74\%. 


\section{DISKUSI}

Orientasi penelitian ini adalah mengetahui tata kelola perusahaan dan risiko keuangan terkait dengan kinerja perusahaan perbankan. Hasil Penelitian menunjukkan variabel tata kelola perusahaan perbankan, risiko pasar, dan risiko likuiditas berpengaruh positif terhadap kinerja bank (ROA). Hal ini dibuktikan dengan probabilita GCG, NIM, dan NPL lebih kecil daripada signifikansi level $(<0.05)$. Sebaliknya pengaruh variabel risiko kredit dan risiko likuiditas operasional terhadap kinerja bank (ROA) adalah berlawanan arah (negatif), artinya semakin tinggi nilai Non Performing Loan (NPL) dan Loan Deposit Ratio (LDR) menyebabkan penurunan pada kinerja bank yang tercermin dari rasio laba terhadap asset bank (ROA). Penurunan kinerja bank ini sendiri akan berdampak pada menurunnya nilai perusahaan perbankan.

Terkait dengan tata kelola perusahaan perbankan, hasil penelitian ini konsisten dengan hasil penelitian (Ghalib, 2018) yang meyimpulkan bahwa tata kelola perusahaan perbankan di Indonesia memiliki hubungan positif dengan kinerja perbankan. Hal ini mencerminkan bahwa dengan kemampuan perusahaan dalam mengelola usaha melalui pembentukan struktur, mekanisme, dan hasil usaha dapat meningkatkan kinerja perusahaan itu sendiri. Dimana perusahaan perbankan di Indonesia harus tetap mempertahuankan prinsip dasar tata kelola perusahaan (GCG), yang meliputi: transparansi, akuntabilitas, responsibilitas, independensi, dan kewajaran. Hal ini dapat terlihat juga pada pernyataan laporan keuangan tahunan bank yang menyatakan ada keterkaitan antara tata kelola perusahaan yang baik dengan kinerja perbankan.

Terkait dengan risiko keuangan perusahaan perbankan, hasil penelitian ini konsisten dengan hasil penelitian (Attar et al., 2014), (Buchory, 2015), (Capriani dan Dana, 2016). (Attar et al., 2014) meneliti efek manajemen risiko implementasi (kredit, likuiditas, dan operasi) pada keuangan kinerja bank yang terdaftar di BEI. Manajemen risiko diukur menggunakan NPL, LDR, dan ETOI. Hasil penelitian menunjukkan bahwa penerapan manajemen risiko kredit, likuiditas, dan operasi secara simultan mempengaruhi kinerja keuangan bank. Namun, penerapan sebagian dari manajemen risiko likuiditas tidak mempengaruhi kinerja keuangan bank.

(Buchory, 2016) menganalisis pengaruh risiko kredit terhadap profitabilitas Bank Pembangunan Daerah. Dia menemukan bahwa LDR tidak memiliki efek negatif yang signifikan pada ROA, ETOI memiliki efek negatif yang signifikan pada ROA, dan NPL tidak berpengaruh positif yang signifikan terhadap ROA. (Capriani dan Dana, 2016) membuktikan bahwa rasio kredit berpengaruh positif dan tidak signifikan terhadap profitabilitas bank, risiko operasional berpengaruh negatif signifikan terhadap profitabilitas bank, dan risiko likuiditas berpengaruh positif signifikan terhadap profitabilitas bank.

Hasil penelitian bertentangan dengan penelitian (Soyemi et al., 2014) yang meneliti hubungannya antara praktik manajemen risiko yang diukur dengan rasio NPL, rasio likuiditas, rasio biaya terhadap pendapatan, dan rasio kecukupan modal dan kinerja keuangan yang diukur dengan ROA dan ROE pada DMB di Nigeria. Penelitian ini menggunakan sampel data dari delapan Bank komersial yang dipilih. Hasil penelitian menemukan bahwa ada efek signifikan dari praktik manajemen risiko bank pada kinerja keuangan perbankan. Namun, sementara risiko kredit dan risiko modal menunjukkan pengaruh positif signifikan terhadap ROA, hanya risiko kredit yang signifikan yang berkontribusi pada ROE. 
Besaran pengukuran rasio NPL (Non Performing Loan) digunakan untuk mengukur jumlah kredit yang diberikan oleh bank dibandingkan dengan jumlah kredit yang bermasalah. Semakin besar jumlah kredit yang diberikan maka semakin besar risiko kredit yang bermasalah. Rasio NPL juga dipengaruhi oleh faktor lainnya, seperti suku bunga kredit perbankan dan kebijakan kredit Bank Indonesia.

Terkait hasil penelitian risiko pasar yang diproksikan Net Interest Margin (NIM), hasil penelitian konsisten dengan hasil penelitian (Zhongming et al., 2019). Menurut (Zhongming et al., 2019) indikator dari risiko pasar yang digunakan dalam penelitian memberikan dampak yang sangat kuat terhadap kinerja keuangan dari bank di Ghana. Hasil penelitian menemukan analisa sebab akibat mengungkapkan bahwa hubungan sebab akibat bergerak searah dari indikator risiko pasar menuju pengembalian asset (ROA).

Pada perusahaan perbankan, rasio NIM digunakan untuk mengukur sejauh mana kemampuan manajemen mengelola aktiva produktif yang berdampak pada besaran laba bersih perusahaan perbankan. Jika suatu bank dapat meningkatkan rasio NIM, maka menunjukan kemampuan bank terhadap strategi bisnisnya yaitu untuk mendapatkan keuntungan, meminimalkan tingkat suku bunga deposit, dan memaksimalkan tingkat suku bunga pinjaman.

\section{KESIMPULAN}

Tata kelola perusahaan perbankan dan risiko keuangan memiliki implikasi terhadap kinerja perbankan di Indonesia. Hasil penelitian juga menunjukkan bahwa variabel tata kelola perusahaan perbankan (GCG), Net Interest Margin (NIM), dan Loan Deposit Ratio (LDR), dan memiliki hubungan searah (positif) terhadap kinerja perbankan (ROA), yang artinya bank harus meningkatkan tata kelola perusahaan, stratetgi bisnis, dan likuiditas bank agar kinerja perbankannya meningkat.

Sedangkan variabel Non Performing Loan (NPL) dan Expense to Operating Income (ETOI) memiliki hubungan berlawanan arah (negatif), yang artinya bank harus menurunkan kredit bermasalahnya dan biaya operasionalnya jika ingin meningkatkan kinerja banknya.

Dengan diterapkannya prinsip-prinsip Good Corporate Governance maka masyarakat luas percaya pada perusahaan perbankan tersebut, masyarakat akan mempercayakan penyimpanan uangnya baik berupa tabungan, giro maupun deposito pada perbankan tersebut, sehingga akan mempertinggi Dana Pihak Ketiga yang pada gilirannya kinerja perbankan pun meningkat (Riyadi dan Raffii, 2018). Mempertimbangkan bahwa bank menghadapi berbagai resiko yang dapat menyebabkan dampak bagi kinerjanya, penting bagi manajemen untuk mengurangi resiko dengan melakukan manajemen resiko yang efektif. Manajer dapat menerapkan prinsip manajemen resiko yang komprehensif dalam setiap jenis resiko seperti resiko kredit, resiko likuiditas dan resiko operasional, karena setiap resiko berperan terhadap unjuk kerja bank.

Saran. Implikasi manajerial dari penelitian ini adalah perbankan yang menerapkan tata kelola perusahaan baik memiliki kinerja yang lebih baik. Meskipun berbagai regulasi terkait dengan tata kelola perusahaan telah diterapkan oleh pemerintah, namun masih cukup banyak bank dasih banyak perusahaan perbankan yang belum mengimplementasikan prinsip-prinsip tata kelola, jika pun ada, kualitas implementasinya baru pada tahap untuk pemenuhan persyaratan regulasi saja. Hal ini ditunjukkan dari 
banyak bank yang belum menyediakan data indeks tata kelola perusahaan. Oleh karena itu, bank-bank dapat menerapkan tata kelola perusahaan baik sehingga kinerjanya meningkat.

\section{DAFTAR PUSTAKA}

Agrawal, A., Knoeber, C. R., Agrawal, A., and Knoeber, C. R. (2013). Corporate Governance and Firm Performance. In The Oxford Handbook of Managerial Economics. $\quad$ England: Oxford University Press.https://doi.org/10.1093/oxfordhb/9780199782956.013.0022.

Alshatti, A. sulieman. (2015). The effect of credit risk management on financial performance of the Jordanian commercial bank. Investment Management and Financial Innovations, 12(1-2), pp.338-345.

Anginer, D., Demirguc-Kunt, A., Huizinga, H., and Ma, K. (2018). Corporate governance of banks and financial stability. Journal of Financial Economics, Elsevier, vol 130(2), pp. 327-346. https://doi.org/10.1016/j.jfineco.2018.06.011.

Apătăchioae, A. (2015). The Performance, Banking Risks and their Regulation. Procedia Economics and Finance, Elsevier, vol 20, pp.35-43. https://doi.org/10.1016/s22125671(15)00044-1.

Attar,D, Islahuddin, Shabri, M. (2014). Pengaruh penerapan manajemen risiko terhadap kinerja keuangan perbankan yang terdaftar di bursa efek Indonesia. Jurnal Akuntansi Pascasarjana Universitas Syiah, 3, pp.10-20.

Buchory, H. A. (2016). Determinants of banking profitability in Indonesian regional development bank. Actual Problems of Economics,177, pp. 303-318.

Butaru, F., Chen, Q., Clark, B., Das, S., Lo, A. W., and Siddique, A. (2016). Risk and risk management in the credit card industry. Journal of Banking and Finance, 72, pp. 218239. https://doi.org/10.1016/j.jbankfin.2016.07.015.

Capriani, N., dan Dana, I. (2016). Pengaruh Risiko Kredit, Risiko Operasional, dan Risiko Likuiditas Terhadap Profitabilitas BPR Di Kota Denpasar. E-Jurnal Manajemen Universitas Udayana, vol 5, 3, pp. 1486-1512.

Chai, B. B.-H., Tan, P. S., and Goh, T. S. (2016). Banking Services that Influence the Bank Performance. Procedia - Social and Behavioral Sciences, vol.224, pp. 401-407. https://doi.org/10.1016/j.sbspro.2016.05.405.

Darrough, M. N., and Stoughton, N. M. (1986). Moral Hazard and Adverse Selection: The Question of Financial Structure. The Journal of Finance. https://doi.org/10.1111/j.1540-6261.1986.tb05051.x.

Drehmann, M., and Nikolaou, K. (2013). Funding liquidity risk: Definition and measurement. Journal of Banking and Finance, 13,1,pp. 231-248. https://doi.org/10.1016/j.jbankfin.2012.01.002.

Drigă, I., and Dura, C. (2014). The Financial Sector and the Role of Banks in Economic Development. Financial Developement and Economic Growth, pp. 598-603.

Ekadjaja, M., Ekadjaja, A., and Henny. (2020). Determinants of company decision making for foreign exchange hedges. International Journal of Innovation, Creativity and Change, Vol 12,issue 3, pp.197-210.

Fang, J., Lau, C. K. M., Lu, Z., Tan, Y., and Zhang, H. (2019). Bank performance in China: A Perspective from Bank efficiency, risk-taking and market competition. Pacific 
Basin Finance Journal, vol.56, pp.290309.https://doi.org/10.1016/j.pacfin.2019.06.011.

Fanta, A. B. (2013). Corporate Governance and impact on Bank Performance. Journal of Finance and Accounting, Vol.1,1, pp. 19-26. https://doi.org/10.11648/j.jfa.20130101.12.

French, N. (2019). Predicted property investment returns: risk and growth models. Journal of Property Investment and Finance, 37(6):580-588.https://doi.org/10.1108/JPIF-072019-0096.

Ghalib, S. (2018). Good corporate governance rating and bank profitability in Indonesia: Evidence from panel data. International Journal of Business and Society. vol. 19, no.3, pp. 570-586.

Hamdani, M. (2016). Good Corporate Governance (GCG) dalam Perspektif Agency Theory. Semnas Fekon 2016.

Haryati, S., and Kristijadi, E. (2015). The Effect of GCG Implementatio and Risk Profile On Financial Performance At Go-Public National Commercial Banks. Journal of Indonesian Economy and Business. https://doi.org/10.22146/jieb.v29i3.6471

How, J., Verhoeven, P., and Abdul Wahab, E. A. (2014). Institutional Investors, Political Connections and Analyst Following in Malaysia. Economic Modelling. 43: pp. 158167. DOI. 10.1016/j.econmod.2014.07.043.

Gugler, K., and Peev, E. (2018). The persistence of profits in banking: an international comparison. Applied Economics. 50(55), pp. 5996-6009. https://doi.org/10.1080/00036846.2018.1489111.

How, J., Verhoeven, P., and Abdul Wahab, E. A. (2014). Institutional investors, political connections and analyst following in Malaysia. Economic Modelling, Vol.43, pp.158167. https://doi.org/10.1016/j.econmod.2014.07.043.

Indonesia, I. B. (2015). Bisnis Kredit Perbankan. Jakarta : PT Gramedia Pustaka Utama.

Jensen, N., and Meckling, W. (1976). Theory of the firm: Managerial behavior, agency costs, and capital structure. Journal of Financial Economics.

Karim, R. Al, and Alam, T. (2013). An Evaluation of Financial Performance of Private Commercial Banks in Bangladesh: Ratio Analysis. Journal of Business Studies Quarterly, 5(2), pp.65-77.

Kasmir. (2014). Bank dan Lembaga Kuangan Lainnya. Jakarta: PT. Raja Grafindo Persada.

Michael Armstrong. (2017). Armstrong's Handbook of Performance Management. Britain:Kogan Page. Ean: 9780749481209.

Million, G., Matewos, K., and Sujata, S. (2015). The impact of credit risk on profitability performance of commercial banks in Ethiopia. African Journal of Business Management, 9(2):59-66. https://doi.org/10.5897/ajbm2013.7171.

Nariman, A., and Ekadjaja, M. (2018). Implikasi corporate governance, investment opportunity set, firm size, dan leverage terhadap earnings quality. Jurnal Ekonomi, vol.23, no.1, pp. 33-47. https://doi.org/10.24912/je.v23i1.332.

Olamide, O., Uwalomwa, U., and Uwuigbe, O. R. (2014). The effect of risk management on bank's financial performance in Nigeria. In Vision 2020: Sustainable Growth, Economic Development, and Global Competitivenes, Proceedings of the 23rd International Business Information Management Association Conference, IBIMA 2014.

Ostadi, H., and Monsef, N. (2014). Assessing the Impact of Bank Concentration and 
Liquidity of Refah Bank Branches on Profitability during the Period1383-190. International Journal of Human Resource Studies. https://doi.org/10.5296/ijhrs.v4i1.5644.

Pyle, D. H. (1999). Bank Risk Management: Theory. In Risk Management and Regulation in Banking, pp. 7-14. https://doi.org/10.1007/978-1-4615-5043-3_2.

Riyadi, S., dan Raffii, R. M. (2018). Pengaruh Dana Pihak Ketiga, Capital Adequacy Ratio, Bi Rate, Dan Financing To Deposit Ratio Terhadap Pembiayaan Murabahah Pada Bank Syariah Di Indonesia. Perbanas Rerview, vol.3, no.2, pp. 65-81.

Soyemi, K. A., Ogunleye, J. O., and Ashogbon, F. O. (2014). Risk management practices and financial performance : evidence from the Nigerian deposit money banks ( DMBs ). The Business and Management Review, vol. 2, Issue 5, pp. 3139.https://doi.org/10.1108/IMEFM-01-2013-0002.

Sugiyono. (2016). Memahami Penelitian Kualitatif. Bandung: Alfabeta.

Trad, N., Trabelsi, M. A., and Goux, J. F. (2017). Risk and profitability of Islamic banks: A religious deception or an alternative solution? European Research on Management and Business Economics. Elseiver, Vol. 23, Iss. 1, pp. 40-45 https://doi.org/10.1016/j.iedeen.2016.09.001.

Wang, Z., Wang, N., and Liang, H. (2014). Knowledge sharing, intellectual capital and firm performance. Management Decision, vol.52, issue 2, pp. 230-258. https://doi.org/10.1108/MD-02-2013-0064.

Yegon, C., Jane, S., and Kirui, J. (2014). The Impact of Corporate Governance on Agency Cost: Empirical Analysis of Quoted Services Firms in Kenya . Research Journal of Finance and Accounting, vol.5, no.12, pp.145-154.

Zhongming, T., Mpeqa, R., Mensah, I. A., Ding, G., and Musah, M. (2019). On the Nexus of Credit Risk Management and Bank Performance: A Dynamic Panel Testimony from Some Selected Commercial Banks in China. Journal of Financial Risk Management, 08(02):125-145. https://doi.org/10.4236/jfrm.2019.82009. 